\author{
Dominika Łarionow \\ (1) https://orcid.org/0000-0002-6920-6360 \\ Department of Art History, University of Łódź \\ larionow@gazeta.pl
}

\title{
IS STAGE DESIGN A CRAFT OR ART?
}

\begin{abstract}
The article draws attention to the problem with the definition of the concept: "scenography." In the twentieth century, theater terminology underwent a number of changes. In the 1960 s, the stage designer ceased to be a decorator, member of technical staff or even a craftsman, and became a theater artist. Currently, stage design/scenography has become an autonomous field of art, present also outside the sphere of theater building: in film, at social demonstrations, political rallies, rock concerts and in museums. The author discusses a change in the approach to the common understanding of the tasks and functions of scenography on the example of the terminology present in the language and theater dictionaries of Anglo-Saxon culture.
\end{abstract}

Keywords: scenography, set design, theater, Prague Quadriennale of Peformance Design and Space

Arnold Aronson, American theoretician and set designer, in one of his texts nostalgically mentioned admiration when, as a student, he looked at engravings depicting stage design by Giuseppe Galli da Bibiena (1696-1757). The researcher's reflection referred to the 1970s, to the period of aesthetic dominance of Jerzy Grotowski's "poor theater". Baroque decorations, full of splendor, associated with the triumph of the convergent perspective making the stage space a vivid picture, turned out to be fascinating for the young American, especially in contrast with the purist saving of the theater of the second half of the last century. The theater at that time was almost entirely filled by the perfectly built body of Ryszard Cieślak, the "total actor" of the 13 Rows Theater. The clash of opposite artistic worlds that divided two centuries showed a change that took place in thinking about the role and tasks that stood in front of the stage designer. The creation of artificial reality, invented for the purpose of presenting was and still is a separate art form, because it is clearly subject to the aesthetics associated with the tendencies of the era. Aronson wrote: 
"This vision of Baroque splendor was a stunning revelation. If one purpose of art - some would argue the purpose - is to create something we cannot experience in our quotidian existence, then was an example of the power and potential of scenography to create previously unknown worlds. The Bibienas expended ideas of what scenography could accomplish [...]."

The power of scenery noticed by the researcher unintentionally links its definition with a fairly important term: art. Both concepts have undergone interpretative transformations in over the last hundred years. As a result of the aesthetic turns of the twentieth century, they have become just as hybrid and completely undefinable. In terms of scenography, researchers should be surprised by the fact that in some dictionaries of theatrical terms, visual art on the stage is still considered a craft that performs service functions in relation to the work of the director or actors. Decoration is understood only as part of a theatrical work that does not produce separate artistic quality. Meanwhile, Patrice Pavis noticed that in contemporary theater, "the set designer is aware of his significance, autonomy of his art and his original contribution to the production of the performance. Left behind for centuries as a background painter in the shadow of an actor or director, he has now become an independent creator of stage and theater space." ${ }^{2}$ But despite such bold phrases, the French researcher, after discussing the transformations of contemporary stage design, concludes his argument with the following statement:

"All such scenography practices have made contemporary stage design a dynamic and multifunctional component of a theater performance." 3

Pavis finally refused the scenery of artistic independence, making it only a "component" of the whole which is a theatrical performance. In this interpretation, decoration has become appreciated, but it is a passive element, creating its own meaning only towards others. Aronson, however, noticed a significant semantic change that took place in relation to the profession of stage designer in the last century. He noticed the incredible expansion of stage design in the 20th and 21st centuries beyond the space and contexts of the theater. He did not only mean the invention of the cinema, which began to use the scenery quite quickly, but also about museums, public rallies, rock concerts, television programs, requiring the creation of various forms of visual art.

Since 1975, the Nordic Theater Union, in cooperation with OISTAT (International Organization of Scenographers, Theater Architects and Techni-

1 A. Aronson, "Foreword", in: Scenography expanded. An introduction to contemporary performance design, ed. Joslin McKinney and Scott Palmer, Bloomsbury 2017, p. 13.

2 P. Pavis, Słownik Terminów Teatralnych, transl. Sławomir Świontek, Wydawnictwo Zakład Narodowy imienia Ossolińskich, Wrocław, 1996, p. 455.

3 Ibidem, p. 456. 
cians), began publishing New Theater Words, which contains entries about professions with competences related to theater. The dictionary is updated every ten years and currently has editions in several languages. Aronson noticed that in the English part a separate entry "scenography" was placed in 1995. In previous editions were: "decor", "scenery", "scenic designer", "lighting designer". This means that the profession became independent only at the end of the 20th century. Previously, the set designer was treated only as a craft specialization working in the theater. The observation also clearly depreciates the possibility of understanding the presence of the stage designer in the theater until the end of the 20th century as an artistic activity, as it happened in the 19th century in the case of a director or actors. The problem also concerns the individual element of the set in the meaning of the artifact, which may have the status and value of a museum object. Rachel Hann ${ }^{4}$ even states that the establishment of OISTAT as a professional organization in 1968 accelerated the process of becoming independent of the stage designer. Both Aronson and Hann indicate that Czech Josef Svoboda (1920-2002) was the first artist to show in his works the narrative distinctiveness of the stage design.

Svoboda began working as a stage designer during World War II. In 1958 at the International Expo in Brussels he prepared two spatial arrangements using screens and rear projection. Helena Albertova in the artist's recently published biography described two short etudes then shown in the Czech pavilion:

„For this synthetic performance Svoboda created a collage of filmed and still projections on a system of screens set in space. The composition refuted the realistic and the real - that is, the actual corresponding proportions between projection and in relationship to the live actors appearing on stage. Projectors, of films and slides, are the common denominator between space-creating projections (A Sunday in August) and projection theater (Laterna magica); the result is a different effect visually and spatially, These two approaches, distant from each other at the start, were the poles of Svoboda's projection/luminous theater; gradually they began to come together, to influence and overlap, and with the development of new luminous and material technologies, to enrich and transform." 5

Svoboda's success in Brussels was important to him for several reasons. Firstly, he became a precursor of modern scenery, changing its meaning forever, thus, as an artist, he went down in the history of theater. Secondly, Svoboda probably unintentionally became officially an important person for the propa-

4 R. Hann, Beyond Scenography, Routledge, 2019.

5 H. Albertovà, Josef Svoboda. Scenographer, Divadelní ústav, Praha, 2008, p. 50. 
ganda of communist Czechoslovakia. However, political aspect of art, which after the World War II was an inseparable part of the reception of artists from the so-called Eastern Bloc countries, is not the subject of this article. I mention this because in the artist's monographs political dependence is associated with the development of his career in the 1960s, seventies and eighties of the last century. ${ }^{6}$

The most important fact in the presented context is that since the Czech show in Brussels, the stage design has definitively ceased to perform a decorative function, it has become an active creative element of the performance, which can independently build the meaning of the message. This change is emphasized in all publications on contemporary history of scenography. Joslin McKinney and Scott Palmer emphasized the pioneering nature of the work of the Czech artist:

"Josef Svoboda, who pioneered scenography techniques using the material qualities of light, thought of scenographic stage as a psycho-plastic space that would materialize at the moment of performance in the presence of an audience; true scenography is what happens when the curtain opens and can't be judged in any other way (Svoboda). This concept of scenography is clearly much more than scene painting. No longer associated only with the static visual image, scenography is multi-sensorial and dynamic, both responsive to and constitutive of dramatic action."7

Aronson sees Svoboda's role in a broader terminological context. In 1971, Jarka Burian biographer of the Czech artist, published an album titled Scenography of Josef Svoboda. The book had a significant impact on the reception of the artist's work, and was an important event, noticed by the authors of the Oxford English Dictionary. They then introduced the entry: "scenography", defining it inter alia in relation to Burian's book. The authors of the British dictionary have noticed that this is a return of a term that dates back to the eighteenth century and is used to refer to the exquisite image created by the illusory theater decoration. Aronson commented:

"The international reputation of Svoboda, however, gave it a hitherto unprecedented prominence. Here was someone who was not merely a designer, a designation that still was redolent of craft rather than art, he was a scenographer; and he did not merely create set designs or lighting designs for the stage, he created something more comprehensive and central to the conception of theater: he created scenography." 8

Cf. H. Albertovà, Josef Svoboda. Scenographer, Divadelní ústav, Praha 2008.

J. McKinney and S. Palmer, "Introducing 'Expanded' Scenography" in: Scenography Expanded. An introduction to contemporary performance design, eds. J. McKinney and S. Palmer, Bloomsbury, 2017, p. 5.

8 A. Aronson, Introduction, The Routledge Companion to Scenography, ed. A. Aronson, Routledge, 2018, p. 2. 
Svoboda's creation of the scenography as an independent field entailed various consequences. Aronson is right, that with the Czech artist a new field of art was born, and thus the craft associated with the presence of a decorator in the theater disappeared. In Polish theater reflection, we can note some success in this field because Zenobiusz Strzelecki, a scenography researcher and historian, made a significant terminological demarcation in 1963:

„The nineteenth-century decorator is only a technician: he knows the painting technique, the technique of changing decorations and the technique of visual effects well. The contemporary set designer interprets the dramatic text (staging) and creates original works of art in spatial and color composition, like any artist: painter, sculptor, graphic artist "9.

However, Strzelecki was primarily a stage designer, and he became a historian to some extent by accident. He wrote a lot, knew the trends in art and was able to link the development of theatrical art of the twentieth century to transformations in aesthetics and contemporary drama. This is how he placed the scenography as an artistic discipline dependent on the influence of literature and art.

"Scenography is theatrical fine art, that is, it is subject to the laws of art and theater at the same time, so its development must be combined with the evolution of easel painting and the evolution of staging, drama, architecture and theater technique." 10

The Polish researcher sensed the need to find a separate place for the scenography among contemporary types of arts. The theatrical fine art is the result of various techniques, eclecticism is its main advantage. Undoubtedly, the scenography/ stage design over the last hundred years has changed not only the world of old theater fine arts into a space of visual narrative, but above all has gone outside the theater building. The stage design, among other things, took over the film treated as a separate artistic form, requiring the use of other means, but also began to construct the entire public and entertainment space in various meanings of the term. Strzelecki's important statements regarding the stage designer who "cannot be a technician but a fine artist"11 seem to be insufficient today because the competences of the contemporary stage designer are of wider significance. They include not only artistic issues, but are combined with the spatial knowledge of the architect, psychological science of social manipulation and the excellent eye of the film operator. Scenography has become omnipresent. An example is the great entertainment and spatial assumption of Efteling in the Netherlands. The architect was a stage designer

9 Z. Strzelecki, Polska Plastyka Teatralna, PIW, Warszawa 1963, p. 16.

10 Ibidem, p. 58.

11 Ibidem, p.133. 
with knowledge of the fictional world of fairy tales and the ability to spatial arrangement of an amusement park. The whole has become a coherent composition organizing on several dozen hectares of land a large playground for people of different ages who will find the right fun in a uniformly aesthetically pleasing space. Emerging land use plans in urban agglomerations are also fascinating. Since the nineteenth-century reconstruction of Paris, urban space has become an area accumulating meaning and quality in various districts, creating social narratives by means of squares and streets. Rock concerts are a completely separate sphere of the presence of the scenography, which in the twentieth century began to be the dominant entertainment of pop culture, which through the performance began to control the imagination of the viewer. The quality of the musical performance, its aesthetics, and dramaturgy created the surroundings of the star, building myths, creating attitudes, fashions etc. We must also mention politics, which in the propaganda sense has used the scenography since ancient times. Currently, the arrangement of processions, rallies, marches, important funerals, apart from directly influencing the viewers, must also have the power to influence the multimedia viewer. Plastic signs therefore have a special role, because they must interact with various media.

Undoubtedly, the expansion of the scenography as a field of art began in 1967, when the first international Quadriennale of Peformance Design and Space was held in Prague. The aim of the world exhibition was to show the widest possible achievements of set designers and architects from around the world. The artists never presented themselves individually, they only exhibited works in national pavilions. From the very beginning, PQ took the form of a competition in which both individual stage designers and costume designers were awarded, as well as the arrangement of individual stands. Currently, separate categories are associated with new technological possibilities of stage design, the sound or multimedia use is being judged.

The Prague meetings in June have gained an extraordinary reputation over fifty years. They attract an increasing group of set designers, design enthusiasts and researchers. In the new millennium, PQ ceased to be an international exhibition, which usually occupied the Art Nouveau building of the Industrial Palace (Výstaviště Praha). Now every four years there are scientific conferences, performance shows and book presentations in Prague. The competition protocol has been significantly expanded, a number of new categories have been added, including publications on scenography, which means that PQ also binds two worlds: researchers and practitioners - qualitatively changing the discourse of ongoing debates.

Despite the recent accumulation of scenography expansion, no one was tempted to formulate a concise definition that would become a clear slogan or terminological emblem of the field. Rachel Hann analyzed all terminology 
trends originating in various areas, both philosophy and theater studies or art history. The British researcher recognized that the crucial determinant for the stage design is the sphere of light and sound manipulation in relation to some spaces through which meaning is created. "Scenography is a navigation of the immaterial effects of sound and light, as well as the subjectivities of tempo and objective dimensions of physical matter." 12 It seems that the definition of Hann refers the scenography too much to the sphere of the construction of atmospheric entities with fleeting materiality. Meanwhile, the scenography's raw material is real, technically perfect. Of course, it must be admitted that through the artwork, the set designer builds the atmosphere of a given performance, its poetic or metaphorical character. However, I think that based on the transience of the atmosphere created by decoration, we skip many important issues. Scenography is not only the art of arranging space, it is the creation of objects existing in three dimensions. Props, objects arranged according to the principles of composition in the space of the stage, construct a narrative that can be used not only for the theater performance but also for public space. An excellent example is the Józef Piłsudski square in Warsaw, who involuntarily became a national scene. For the past fifty years, monuments relating to important events in the history of the twentieth century and the beginnings of the new millennium have been placed on it. Their arrangement is purposeful, together they build a historical narrative that will one day accurately reflect the events of the era in which it was created.

Arnold Aronson, as a theoretician who has been researching the transformations of the theater space for years, seeing the expansion of the scenery getting stronger formulated a more accurate definition:

"Scenography [...] is the all-encompassing visual construct of the theatrical event and embodies the process of change and transformation that is an inherent part of the physical vocabulary of the stage." 13

The terms "theater" and "stage" appearing above can be applied to all artistic forms of a performative nature. In Aronson's definition, the most important observation is the transfer of the meaning of the word 'visual art' to 'physical vocabulary'. This means that scenography is the primary language in shaping the visual message, however understood. Of course, one should consider whether the stage design does not lose artistry in favor of becoming the first form - the mystical materia prima. The visual setting of the performances is first and foremost a semantic subcode, which is subject to aestheticization in line with the tendency of the era for which it is created. As history shows, there

12 R. Hann, Beyond Scenography, op. cit, p. 21.

13 A. Aronson, Looking into the Abyss. Essays on Scenography, University of Michigan, 2005, p. 7. 
are many activities and artifacts within the set design that exist outside the contexts of the performances for which they were created. A good example can be the art of Tadeusz Kantor, whose stage works, especially after the author's death, often becomes the basis for the creation of exhibitions devoted to his work. The same happened with the work of Stanley Kubrick. ${ }^{14}$

For Aronson, the arrangement of the space of the Polin Museum of the History of Polish Jews in Warsaw has become a modern area for the presence of scenography. The exhibition was not created from exhibits of historical value, but through set design using specially prepared artifacts. Therefore, it can be said that the narrative of the exhibition about the history of Jews was entirely produced by means of scenography, which by its nature can use a false element only an object that is artificial or mimicking the real. The organizers of two Gdańsk museums: Museum of the Second World War and the European Solidarity Center, used a similar approach to the decoration as the setting, which creates the semantic sequence of the exhibition. Thus, the attractiveness of museums is built not only on the quality of the presented objects, but on the scenography that creates the entire exhibition. One can conclude that contemporary museums make the most of the expansion of scenography as an independent field of art.

The Prague Quadrennale in 2019 showed that there are no boundaries to cross for the scenography. It is everywhere like before happenings or performances use to be the basis for the creation of performances, costume shows, arrangement of meetings, even a subtle structure that allows to build a mezzanine in the exhibition pavilion as a buffet space. The world exhibition in Prague has also proved that even technologies can be posed by scenography. VR projections were the dominant element of most national pavilions. They were used in terms of services: to present fragments of performances, but you could also take a virtual walk around the studio of the stage designer, and even see him at work. Only the organizers of the Polish position went a bit further. They offered the public a virtual walk around the imaginary city. ${ }^{15}$ The VR projection had nothing to do with real stage design for any theater or film show. She was like a separate work whose viewer became a passive observer for twenty minutes. He entered the virtual world, was led through the entire space, he could see it carefully, but could not change anything in it. The question may be asked

14 See D. Łarionow, Co to jest scenografia? Kilka uwag historycznych i metodologicznych in: Odstony wspótczesnej scenografii. Problemy - sylwetki - rozmowy, ed. K. Fazan, A. Marszałek, J. Rożek-Sieraczyńskiej, Wydawnictwo Uniwersytetu Jagiellońskiego, Kraków 2016, p. 19-36.

15 Aporia. The city is the city, kuratorzy: A. Wasilkowska and K. Garbaczewski, Instytut Teatralny im Zbigniewa Raszewskiego w Warszawie. 
whether VR is the future for the shows of post-modern societies? Will scenographers work in the next decades of the new millennium against real objects or only to create non-existent surreal spatial forms? For now, the questions remain unanswered.

The famous Italian family of stage designers Galli da Bibiena changed the appearance of the scenery of the seventeenth and eighteenth centuries, bringing painting forms from the rigid frames of prospectuses. The artists achieved the highest craftsmanship in building the illusion of a stage background, using the technique available at that time. Perhaps now multimedia will give set designers an equally important and powerful tool. We can therefore conclude that the once slightly mockingly return of the old term "scenography" recorded by the English dictionary was rather an announcement of another great reform related to the visuality of performances, which Aronson foretold.

\section{BIBLIOGRAPHY:}

Albertovà Helena (2008) Josef Svoboda. Scenographer, Praha: Divadelní ústav.

Aronson Arnold (2005) Looking into the Abyss. Essays on Scenography, University of Michigan.

Aronson Arnold (2018) The history and theory of environmental scenography, London: Methuen Drama, Bloomsbury.

Burian Jarka (1971) The Scenography of Jozef Svoboda, Middletown: Wesleyan University Press.

Hann Rachel (2019) Beyond Scenography, London and New York: Routledge.

Odstony wspótczesnej scenografii. Problemy - sylwetki - rozmowy (2016) ed. by Katarzyna Fazan, Agnieszka Marszałek i Jadwiga Rożek-Sieraczyńskiej, Kraków: Wydawnictwo Uniwersytetu Jagiellońskiego.

Pavis Patrice (1996) Stownik Terminów Teatralnych, transl. Sławomir Świontek, Wrocław: Wydawnictwo Zakład Narodowy imienia Ossolińskich.

Scenography Expanded. An introduction to contemporary performance design (2017) ed. by Joslin McKinney and Scott Palmer, London: Bloomsbury.

Strzelecki Zenobiusz (1963) Polska Plastyka Teatralna, Warszawa: PIW.

The Routledge Companion to Scenography (2018) ed. by Arnold Aronson, London and New York: Routledge. 


\section{CZY SCENOGRAFIA JEST SZTUKA CZY RZEMIOSŁEM? (streszczenie)}

Artykuł zwraca uwagę na problem z definicją pojęcia: scenografia. W dwudziestym wieku terminologia teatralna przeszła szereg zmian. Scenograf od lat sześćdziesiątych ubiegłego stulecia przestał być dekoratorem, osobą techniczną czy wręcz rzemieślnikiem a stał się artystą teatru. Obecnie scenografia stała się autonomiczną dziedziną sztuki, która obecna jest także poza sferą budynku teatralnego: w filmie, w marszach społecznych, politycznych wiecach, koncertach rokowych a także muzeach. Autorka pokazuje zmianę w podejściu do powszechnego rozumienia zadań i funkcji scenografii na przykładzie terminologii obecnej w słownikach językowych i teatralnych kultury anglosaskiej.

Słowa kluczowe: scenografia, plastyka teatru, dekoracje, teatr, Praskie Qudriennale Scenografii

Dominika Łarionow - PhD, lecturer at the Department of Art History, University of Łódź (Poland). She was a convener of Scenography Working Group FIRT/IFTR (2006-2013). She is a member of Editorial Committee “Theater Art Journal”, Tel Aviv University. She publish two books: Przestrzenie obrazów Leszka Mądzika [Spaces of images by Leszek Mądzik], Lublin 2008 and „Wystarczy tylko otworzyć drzwi... Przedmioty w twórczości Tadeusza Kantora [„You only need to open the door...” Items in the works of Tadeusz Kantor], Łódź 2015. 